Volume 2, No. 3, September - December 2017 ISSN: 2503-4235 (p); 2503-4243 (e)

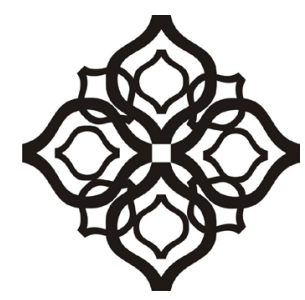

Shirkah

Journal of Economics and Business 


\section{Shirkah}

Journal of Economics and Business

Vol. 2, No. 3, September-December 2017

ISSN: 2503-4235 (p); 2503-4243 (e)

\section{Editor in Chief}

Sri Walyoto

\section{Editorial Boards}

Abu Umar Faruq Ahmad, UBD School of Business and Economics, Brunei Darussalam

Amelia Fauzia,

Asia Research Institute, National University of Singapore, Singapore

Cedomir Nestorovic,

ESSEC Business School Asia Pacific, Singapore

Dwi Condro Triono,

Faculty of Islamic Economics and Business, IAIN Surakarta, Indonesia

Fahmy Radhi,

Faculty of Economics and Business Universitas Gadjah Mada, Yogyakarta,

Indonesia

Hasan Basri,

Syiah Kuala University, Aceh, Indonesia

Johan Fischer,

Department of Social Sciences and Business Roskilde University, Denmark

Masudul Alam Choudhury,

Postgraduate Program in Islamic Economics and Finance, Trisakti University,

Jakarta, Indonesia and the College of Economics and Political Science (CEPS) in

Sultan Qaboos University (SQU), Oman

M. Falik Isbah,

School of Humanities and Social Science, University of New South Wales, Australia M. Ishaq Bhatti,

La Trobe Business School Department of Economics and Finance La Trobe

University, Australia

Najib Kailani,

Pascasarjana, Universitas Islam Negeri (UIN) Sunan Kalijaga, Yogyakarta, Indonesia 
Nunung Nurul Hidayah,

Aston Business School, Aston University, Birmingham, United Kingdom

Shaikh M Ghazanfar,

Departement of Economics, University of Idaho, Russian Federation

\section{Managing Editors}

Fitri Wulandari

Jasanta Perangin-angin

\section{Assistant to Editor}

M. Endy Saputro

M. Zainal Anwar

Supriyanto

Shirkah Journal of Economics and Business is a peer-reviewed journal published three times a year (January-April, May-August and September-December) by Faculty of Islamic Economics and Business, Institut Agama Islam Negeri (IAIN/ State Institute for Islamic Studies) Surakarta Central Java, Indonesia. The main objective of Shirkah is to offer an academic space of exchange ideas and initiate the increase number of qualified article produced by postgraduate students, practitioners and academicians.

\section{Editorial Office}

Ruang Jurnal Shirkah

Ground Floor, West Gate,

Faculty of Islamic Economics and Business

IAIN Surakarta

Jln. Pandawa No. 1, Kartasura, Sukoharjo, Jawa Tengah Kode Pos. 57168

Phone (+62271) 781516 Fax: (+62271)782336

E-mail: shirkahiainsurakarta@gmail.com

Website: http://shirkah.or.id/ 


\section{Shirkah}

Journal of Economics and Business

Vol. 2, No. 3, September-December 2017

ISSN: 2503-4235 (p); 2503-4243 (e)

\section{Table of Contents}

\section{Articles}

B.A Badejo

B.A. Okuneye

M.R Taiwo

Fraud Detection in the Banking System in Nigeria Challenges and

Prospects

Abdul Qoyum

Milzamulhaq Mardiya

Muhammad Rizky Prima Sakti

Indonesian Capital Market Efficiency: Islamic vis-a-vis Conventional

Dita Andraeny

Dessy Diana Putri

Islamicity Financial Performance Index in Indonesian Islamic Banks

Muh. Rudi Nugroho

Flypaper Effect of Regional Expenditures in Yogyakarta

Agus Faisal

Irma Yuliani

375

Productive Zakat of Baznas Yogyakarta on the Growth of Micro Business

Rakhmawati

Sakofa Evaluating Zakat Microfinance Program 


\title{
Flypaper Effect of Regional Expenditures in Yogyakarta
}

\author{
Muh. Rudi Nugroho \\ Faculty of Islamic Economics and Business \\ Universitas Islam Negeri Sunan Kalijaga Yogyakarta \\ muhrudi82@gmail.com
}

\begin{abstract}
One of the consequences as a result of the implementation of regional autonomy is that local governments must have sufficient financial resources to pay their autonomy government. The financial capacity of local governments would determine the ability of local governments to perform the functions of government. Considering Article 5 of Law No. 33, 2004, sources of regional revenue are regional revenues, balance funds/ transfers and financing. When local revenue comes from the transfers, the stimulation of expenditure is different from the stimulation that arises from local revenue (especially local taxes). This study focuses on identifying the flypaper effect on expenditure areas and its classification with samples of five districts and cities in Yogyakarta during 2006-2015. This paper argued that during the period among flypaper did not occur in the expenditure area and sub expenditure areas. In addition, fypaper found only in capital expenditure, while expenditure is not a suspect.
\end{abstract}

Keywords: flypaper, autonomy and fiscal needs, local autonomy, Yogyakarta

\section{Introduction}

Regional autonomy and fiscal decentralization are not a new concept in Indonesia; it has officially been issued in Law No. 5, 1975 on the main points in local government (Sundatoko, 2003). However, the policy of regional autonomy and fiscal decentralization during the New Order government has not been able to reduce inequality of the vertical and horizontal governmental system, which is indicated by the high 
degree of fiscal centralization and the magnitude of inequality between regions and territories (Mauro, 2005). The international practice of fiscal decentralization was implemented on January 1, 2001 based on Law No. 25, 1999 which is enhanced by Law No. 33, 2000 on the financial balance between the central government and local governments. As a consequence of the implementation of the law is that regions should be able to develop regional autonomy broadly, concretely and responsibly in empowering the society, economic institutions, sociopolitical and legal questions (Hermani, 2007).

Capacity of local government finance badly depends on the revenue from the central government. As a consequence, in the framework of decentralization to each region is required to be able to finance themselves through the financial resources under their control (Hermani, 2007). The role of local government in exploring and developing various regional potential as a source of revenue largely determine the successful implementation of government functions, development, and community services in the area (Seabright, 2005). One consequence in the implementation of regional autonomy is that local governments must have sufficient financial resources to finance their autonomy. The financial capacity of local governments determine the ability of local governments to perform the functions of government (Kelvin, 2000). The low fiscal capacity often lead to a negative cycle, namely the low level of public services, which in turn would invite intervention center, or even the transfer of most of the functions of local government into the upper levels of government (Isdijoso and Brahmantio, 2002).

Based on article 5 of Law No. 33, 2004 sources of local revenue are revenues, the balance funds/ transfer and financing. When local revenue comes from transfers, the stimulation of expenditure is different from the stimulation that arises from local revenue (especially local taxes) (Siregar, 
Badrudin, Melo, 2015). Melo (2005) states that a condition in which the larger expenditure areas response to the transfer, it is called fypaper. This technical term is first introduced by Courent, Gramlich, and Rubield (1979) for articulating Arthur Okun's mind (1970) that said "money stick where it hits" in as much as has never same word "flypaper effect" in bahasa Indonesia. The phenomenon flypaper hits wider implications when the transfer will increase local government spending that is greater than the acceptance of its transfer (Turnbull 2008). Maimunah (2006) considers that the phenomenon of flypaper can be happen in two versions. The first refers to the increase in local taxes and excessive government spending. The second leads to the elasticity of spending on higher transfers than the elasticity of spending on local tax revenues.

From the aforesaid, it is interesting to analyze flypaper on Dana Alokasi Umum (DAU/ General Allocation Grant) and Pendapatan Asli Daerah (PAD/ Direct Autonomy Income) to the expenditure district and municipal governments in Yogyakarta, Indonesia. Yogyakarta has been a province with the peculiarities of technocrats, whether it has the same trend as other regions in Indonesia in terms of government spending preferences. This study focused on identifying the flypaper effect on expenditure areas taking samples of five districts and cities in the Yogyakarta province for the periode of 2006-2015. This paper argues that during the period flypaper does not occur in the expenditure area and sub expenditure areas; while the flypaper found only in capital expenditure.

\section{Revealing Regional Autonomy}

In accordance with the mandate outlined in Law No. 5, 1974 on the subject of regional government, the principle of regional autonomy should be real and responsible. Real in the sense that the granting of autonomy is based on such factors as calculations and policies that truly 
warrant the region which should be able to manage her own household. In addition, responsible means autonomy are completely in line with the objective to launch the development scattered throughout Indonesia and in harmony with the political guidance of the unity of the nation. Therefore, there will be a harmonious relationship between the central government and the local one. Furthermore, in the official explanation of Law No. 5, 1974 precedence that the implementation of local government is based on several principles, namely:

a. Implementation of autonomy to the region should support the aspirations of the people's struggle, which is to strengthen the unity of the state and enhance the welfare of the people.

b. The division of autonomy to the regions must be a real and responsible autonomy. The principle of decentralization is carried out in conjunction with de-concentration by also providing the possibility of implementing the task of the principle of assistance.

c. Giving autonomy to the region is to declare the effectiveness and effectiveness of government administration and service to society, political stability and national unity.

Successful implementation of regional autonomy can not be separated from regional capability in finance, due to financial ability become an important indicator in measuring level of regional autonomy. Financial resources can be grouped into two, namely the source of Direct Regional Income (PAD) and the source of Non-direct Regional Income. Implementation of regional autonomy can be achieved if local financial resources can finance local activities derived from PAD (Warner, 2009). The local government in carrying out its households requires a source of income derived from the PAD. Without sufficient funds, the central features of regional autonomy are lost. Although the regions are also getting sources from $\mathrm{PAD}$, but $\mathrm{PAD}$ has a strategic role in providing local finance 
due to for a region, the source of local revenue is the main pillar of the buffer of regional life. Experts therefore often use PAD as an analytically tool in assessing the degree of autonomy of a region (Peck, 2005).

Local governments in implementing various finances with autonomy to regulate and take care of the household would need funds. This shows how important the financial factor is to implement regional autonomy, because there is no government activity that does not require cost, so it requires adequate financial resources for the implementation of local government by exploring the source of PAD, for the main aim of making the dependency of local government with central government would be not too high (Abate, 2004). Practically, managing the government administration with respect to important regional finances is to have self-sufficient local revenue. If PAD revenue has reached $20 \%$ of regional expenditure, then the source of local finance may be said enough; in doing so the dependence of local governments on the central government is small. The large percentage of PAD to regional expenditure, the better the regional autonomy (Abate, 2004). In order to take care of its own household well, the region needs to be given sufficient sources of financing. Nevertheless, remember not all sources of funding can be given to the local region; consequently it is required to dig up all their own financial resources based on laws and issued regulations (Sidik and Soewondo, 2002).

\section{Flypaper Effect, DAU/PAD and Expenditure Area}

Intergovernmental transfers may be an alternative of regional policy to solving the fiscal gap. The act of transfer face two direct phenomena on one hand, it reveals the increase of regional spending; while on the other hand it in line with the increasing transfer of funds from the government. The transfer proposes to exercise to internalize the fiscal which emerge 
in inter-regional development (Melo, 2005; see also Leduc and Wilson, 2017). Ajit and Lalvani (2008) states that the granting of transfer basically aims to increase regional capacity to finance local expenditure greater than transfer administration to increase local governments' efforts excavation area financing sources primarily from the fiscal area. Nevertheless, the transfer of payments results ineffectiveness in financing regional expenditures. The phenomenon is known as fypaper which comprises: (1) an increase in taxes and excessive government spending, (2) the elasticity of spending on transfers higher than the expenditure elasticity of the local tax.

Some studies suggest that income affects financial spending; while others claim vice-versa (Abate, 2004). For thirty years, other research said, that studying the effect of grants from the central government to local government expenditure has been continuously running (Prakosa, 2004). Theoretically, the response will have an allocation of distributive effect that is no different from other funding sources, such as local tax revenues (Prakosa, 2004). However, the expert shows that the case irregularly happen; due to the stimulus for the expenditure incurred by the transfer area or grants are often greater than the stimulus of revenue (taxes) own area (flypaper). Persha and Blomley (2009) states that there is a very close relationship between transfers from the central government and local government spending.

Considering the above results have shown that the General Allocation Grant (DAU) is an important source of income for an area to meet expenditures. This DAU can simultaneously address the level of independence of a region. The more DAU received then the area is still very dependent on the Central Government in fulfilling the expenditure, this indicates that the area does not independent and vice versa. The study of the influence of local revenues (local own-source revenue) in regional spending has been done by proving hypothesis that revenues (mainly 
taxes) would influence local government budget known hypothesis spend $\operatorname{tax}$. In this case, the local government spending will be adjusted to changes in local government revenue or income changes occur prior to the changes in expenditure (Regulska, 2009).

Deller and Maher (2005) have examined that the spending categories with a focus on the area of fypaper, surprisingly found that the effect of unconditional grants on expenditure category is much stronger on the needs of non-essential (luxury) needs such as paying parks and going recreation, consuming cultural and educational services than such the essential needs as paying security and protection against fire. Ajit Karnik and Mala Lalvani (2008) discusses the process of decentralization in the state of Maharashtra. Among the states in India, Maharashtra is considered successful in implementing decentralization. With 243 samples of local government, Lalvani identifies the occurrence of flypaper on spending stimulus grant from the state government to the local governments. In addition, Lewis (2003) in his study with a sample of local governments in Indonesia on the island of Java, Bali, Sumatra, and Borneo has identified also the flypaper. He argue that increased regional spending has implications for the central government's expenditures well. It means that the regions have not been self-sufficient even though regional expenditure has increased. The central government transfers response to regional expenditure more quickly than the PAD response to regional expenditure.

Maimunah (2006) states that regions in the area of Sumatra have got flypaper effect in response to transfer spending of DAU and PAD. She also observed that the flypaper effect have beneficial aim to predict the future period of regional financial spending. There are no differences of taking flypaper effect both in the areas of having low and high PAD in Sumatra. Studying flypaper in Yogyakarta and Central Java has also been performed by Prakosa (2004), arguing that empirically prove that the 
regional expenditures has been influenced by the amount of DAU received from the central government. From the regional expenditure prediction model, DAU's predicted power to regional expenditure is higher than PAD's prediction rate. The above studies have provided the fact that some local governments in Indonesia depend on the central government (cf. Roy, Ara, Das, Quisumbing, 2015; Jeyhoon-Tabar and Maddah, 2016; Baskaran, 2016).

Determining the occurrence of flypaper in this study focused on the comparison of the effect of PAD and DAU Expenditure Area. Melo (2005) and Venter (2007) states that the fypaper occur if (1) the influence/ value of the DAU coefficient on regional expenditure is greater than the effect of PAD on the regional expenditure, and both values are significant; (2) the analysis shows that the influence of the PAD to the expenditure area is not significant, it can be concluded occur the flypaper. It may be described as the following conceptual framework:

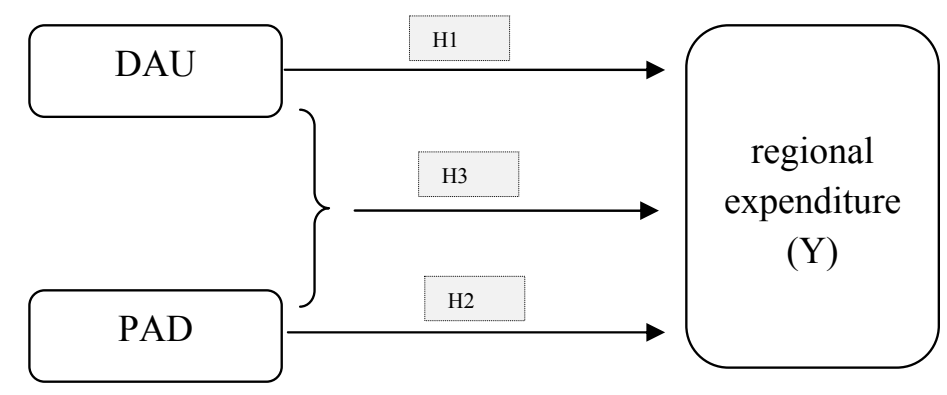

The hypotheses then are formulated:

- H1 : DAU takes positive influence on expenditure areas in DIY

- $\mathrm{H} 2$ : PAD takes positive influence on expenditure areas in DIY

- H3 : The influence of DAU to expenditure areas stronger than the influence of PAD on regional expenditure in DIY. 


\section{Research Methods}

The data of this study takes from realization of budget in Yogyakarta in 2006 -2015. All of this data is secondary data obtained from the Budget Realization Report Revenue and Expenditure Provincial Level in Indonesia were obtained from the Central Bureau of Statistics and the largest Regional Financial Information System, Ministry of Finance of the Republic of Indonesia, Directorate General of Fiscal Balance which may take easily on the internet. The dependent variable is regional expenditure (BD). Regional expenditure is all local government expenditure in a budget period. Based on the Regional Budget, expenditure areas consist of personnel expenditure, spending on goods and services, business travel spending, the maintenance of its spending, capital expenditures, expenditures for the results and financial assistance, as well as expenditure does not suspect (Law No. 32 of 2004).

Personnel expenditure accommodate all public expenditure is used to pay salaries, including allowances they are entitled, and to pay the fees, overtime, vakasi, special allowances and transit personnel expenditures, and to pay pensions and health insurance (social contributions). The classification includes salary / wage expenditures of projects that have been classified as development expenditures. With this format, it will show an overlapping post between personnel expenditures classified as routine and development. This is where the efficiency will be achieved. Likewise, spending on goods that should be used to finance government operations for the procurement of goods and services, and maintenance costs of assets State (Law No. 32 of 2004).

Expenditure goods are spending to accommodate the purchase of goods and services that are consumable to produce goods and services are marketed and not marketed, and the procurement of goods intended to be given or sold to the public and expenditure pe rjalanan (Law No. 
32 of 2004). While, expenditure travel service include expenditures for official travel in the framework of regular operations and surveillance $\mathrm{k}$ e area (Law No. 32 of 2004). In addition, maintenance expenditures include expenditures for utilization in order to maintain power, either in the form of goods moved and goods that do not move in the framework of the continuity of duty and obligation of the government (Law No. 32 of 2004).

Capital expenditure accommodates whole spending country allocated for purchase goods needs investment (in form asset permanent and asset other). Capital expenditure items specified (i) the capital expenditure of assets fixed / physical, and (ii) capital expenditure assets other / non-physical. In practice for this expenditure Other non-physical on majority composed from expenditure employees, flowers and trips that are not related directly with investation for development (Act No. 32 of 2004). Furthermore, expenditure for results and help finance is spending on interest payments (interest) on the use of the principal debt obligations (principal outstanding) were calculated based on the position of short-term loans or long-term (Law No. 32 of 2004).

Expenditure no suspect are budgetary expenditures on unusual and repeated unexpected activities such as natural disaster management, social disaster and other unexpected expenditures indispensable in the context of central / regional government (Law No. 32/2004). Then on first income local are revenues derived from local revenue sources and managed locally by the local government. In the foregoing description pursuant to Law No. 32 of 2004 Article 157 stated that the original revenue of the region consists of:
a. Results tax area
b. Results retribution area
c. Results management wealth
d. Other income original legal area. 
The General Allocation Grant (DAU) is one of the transfers of Government funds to local governments derived from APBN revenues, allocated for the purpose of equitable inter-regional financial capacity to fund regional needs in the context of decentralization. DAU is "block grant" which means the user delegated to the regions in accordance with the priorities and needs of the regions to improve services to the community in the implementation of regional autonomy (Yuliadi, 2007). In addition Special Allocation Fund (Dana Alokasi Khusus/ DAK) are funds given to local governments provincial and regency / city to finance the special activities of local affairs by considering the financial capacity of the area in the budget and with regard to regional eristik char (Yuliadi, 2007).

\section{Estimation of Regression with Panel Data}

Panel model estimation of data depending on the assumptions made investigators to intercept / constant (intercept), the slope coefficient (slope coefficients) and variable error (error term). Regression analysis with panel data is used to answer some hypotheses above. Among these are to know the effect of PAD and DAU on Regional Expenditure. The data obtained will be tabulated and mathematically processed using a computer program (software) E-views 6. The model will be used to identify the effect of the internal variable is the local government;

$$
\begin{aligned}
& Y_{i t}=\beta_{1}+\beta_{2} D A U_{i t}+\beta_{3} D A K_{i t}+\beta_{4} P A D_{i t}+E_{i t} \\
& Y 1_{i t}=\beta_{1}+\beta_{2} D A U_{i t}+\beta_{3} D A K_{i t}+\beta_{4} P A D_{i t}+E_{i t} \\
& Y 2_{i t}=\beta_{1}+\beta_{2} D A U_{i t}+\beta_{3} D A K_{i t}+\beta_{4} P A D_{i t}+E_{i t} \\
& Y 3_{i t}=\beta_{1}+\beta_{2} D A U_{i t}+\beta_{3} D A K_{i t}+\beta_{4} P A D_{i t}+E_{i t} \\
& Y 4_{i t}=\beta_{1}+\beta_{2} D A U_{i t}+\beta_{3} D A K_{i t}+\beta_{4} P A D_{i t}+E_{i t} \\
& Y 5_{i t}=\beta_{1}+\beta_{2} D A U_{i t}+\beta_{3} D A K_{i t}+\beta_{4} P A D_{i t}+E_{i t} \\
& Y 6_{i t}=\beta_{1}+\beta_{2} D A U_{i t}+\beta_{3} D A K_{i t}+\beta_{4} P A D_{i t}+E_{i t} \\
& Y 7_{i t}=\beta_{1}+\beta_{2} D A U_{i t}+\beta_{3} D A K_{i t}+\beta_{4} P A D_{i t}+E_{i t}
\end{aligned}
$$


Remarks:

$Y_{i t} \quad:$ Total Regional Expenditure

$Y 1_{i t} \quad$ : Employee Expenses

$Y 2_{i t} \quad$ : Expenditure for Goods and Services

$Y 3_{i t} \quad$ : Expenditure Travel Agency

$Y 4_{i t} \quad$ : Expenditure Maintenance

$Y 5_{i t} \quad:$ Capital Expenditure

$Y 6_{i t} \quad:$ Revenue Sharing and Financial Aid

$Y 7_{i t} \quad:$ Expenditure Not Suspect

$\beta_{1} \quad$ : Constants

$\beta_{2}, \beta_{3}, \beta_{4}$, : Regression Coefficients

$D A U \quad$ : General Allocation Fund

$D A K \quad$ : Special Allocation Fund

$P A D \quad:$ Locally-generated revenue

E : Error Term

Panel data analysis is the development of regression analysis. There are three basic regression methods that exist, namely the Common Pooled Least Squares, Fixed Effects Regression and Random Effect. To determine the most appropriate method can be done with Hausmann Test, Test Lagrange Multiplier (LM), and Chow Test.

\section{Chow Test}

Chow test is used to choose between the common effect models with fixed effect.

- If Ho is accepted, then the model pool (common).

- If Ho is rejected, then the fixed effect model 


\section{Test Haussman}

Haussman test is used to select between Fixed Effect Model (FEM) or Random Effects Model (REM). The hypothesis of the Haussman test is:

Ho : Random consistent estimator

$\mathrm{Ha} \quad$ : Random estimator inconsistent

When REM Ho accepted means better use than FEM, and vice versa. Then Ho accepted / rejected if:

$$
\begin{aligned}
& X^{2}{ }_{\text {tab> }} X^{2} \text { hits }: \text { Ho accepted } \\
& X^{2}{ }_{\text {the }}<X^{2}{ }_{\text {hits }}: \text { Ho is rejected }
\end{aligned}
$$

To obtain the value $X^{2}$ hits taken from the difference in beta value and covariance of each method. The Haussman statistic test that can be done is (Haussman, 1978):

$$
W=\frac{\left(\bar{\beta}_{F E M}-\bar{\beta}_{R E M}\right)^{2}}{\left(V\left(\bar{\beta}_{F E M}\right)-V\left(\bar{\beta}_{R E M}\right)\right)} \sim X^{2}(1)
$$

and for multivariate,

$$
W=\left(\bar{\beta}_{F E M}-\bar{\beta}_{R E M}\right)\left(V\left(\bar{\beta}_{F E M}\right)-V\left(\bar{\beta}_{R E M}\right)\right)^{-1}\left(\bar{\beta}_{F E M}-\bar{\beta}_{R E M}\right) \sim X^{2}(k)
$$

Haussman statistical test follows the chi-square $\left(X^{2)}\right.$ with as many degrees of freedom $k$, where $k$ is the number of independent variables. If the statistical value Haussman greater than the critical value is the right model of FEM, while conversely if the statistical value Haussman is smaller than the critical value then the right model is REM. According to the Judge (1985), there are some things that must be considered to determine which approach is selected (FEM or REM) in the estimation of panel data:

a) If $\varepsilon$ and $X$ correlated, then it is better to use FEM, and if $\varepsilon$ and $X$ are not correlated, then it is better to use REM

b) If $T$ (number time series) large and $n$ (number individual / 
unit) is small, the difference both relatively small, then more good use FEM

c) If $n$ big and $T$ small, used FEM if the unit is not random from large sample and used $B R A K E$ when the unit is taken on random

d) If $n$ big and $T$ small and if assumption BRAKE met, REM estimators more efficient compared FEM

If the calculation $L M>X^{2}$ with one degree of freedom, then Ho is rejected, meaning that $R E M$ can be used to estimate the regression equation.

\section{Test Lagrange Multiplier (LM)}

Test Lagrange Multiplier (LM) is used to choose between OLS without dummy variables or choose random effect. Test Lagrange Multiplier (LM) that can be done is (Breusch and Pagan, 1980):

$$
L M=\frac{n T}{2(T-1)}\left(\frac{\sum_{i=1}^{n}\left(\sum_{i=1}^{n} e_{i t}\right)}{\sum_{i=1}^{n} \sum_{i=1}^{n} e_{i t}^{2}}-1\right)^{2}
$$

Where,

$n \quad$ : the number of individuals

$T$ : the number of time periods

$e \quad$ : residual method of OLS

If the calculation $L M>X^{2}$ with one degree of freedom, then Ho is rejected, meaning that $R E M$ can be used to estimate the regression equation.

\section{Descriptive Statistics}

Table 1 shows descriptive statistics of the research samples from 50 observations. In general it can be said that the sample data is normally 
distributed. This is seen from the relative mean and median values (little difference), except for Unexpected Expenditure.

\section{Table 1. Descriptive Statistics}

\begin{tabular}{lccccc}
\hline \multicolumn{1}{c}{ Variables } & Mean & Median & Maximum & Minimum & $\begin{array}{c}\text { Standard } \\
\text { Deviation }\end{array}$ \\
\hline Expenditure Area & 583.41 & 559.41 & 779.85 & 458.91 & 86.77 \\
DAU & 523.77 & 520.99 & 701.49 & 370.69 & 95.49 \\
DAK & 27.99 & 32.21 & 44.08 & 4.80 & 12.09 \\
PAD & 83.27 & 70.34 & 163.07 & 35.09 & 43.27 \\
Expenditure Employee & 330.54 & 314.09 & 467.43 & 238.63 & 70.21 \\
Expenditure Goods and & 71.87 & 68.42 & 126.46 & 38.53 & 23.11 \\
Services & 7.07 & 6.94 & 11.94 & 3.29 & 2.19 \\
Expenditure Travel Service & 13.91 & 12.25 & 25.08 & 6.05 & 5.72 \\
Expenditure Maintenance & 90.96 & 83.47 & 137.72 & 65.60 & 18.71 \\
Capital expenditure & 54.80 & 53.33 & 78.50 & 41.68 & 9.49 \\
Expenditure For Results & 13.85 & 4.99 & 52.90 & 1.46 & 17.27 \\
Expenditure No Suspect & & & & & \\
\hline
\end{tabular}

\section{Model Selection}

Before the panel data regression analysis, then tested whether the regression model selection is done with methods common effect, fixed effect and random effect. The initial phase of the chow test to choose between common effect models with fixed effect. by using Eviews 6 software then obtained test Chow test results as in Table 2.

Chow test results showed that the $P$ value is greater than 5 percent ( $P$ value $>$ $5 \%$ ), then the model is recommended and better model between common effect with fixed effect model is Fixed Effect. 


\section{Table 2. Test Results Chow}

\begin{tabular}{llr}
\hline $\begin{array}{l}\text { Dependent } \\
\text { Variables }\end{array}$ & Effects Test & probability \\
\hline & Cross-section F & 0.887508 \\
& Cross-section Chi-square & 0.887419 \\
\hline Cross-section F & 0.869886 \\
Cross-section Chi-square & 0.869797 \\
\hline Cross-section F & 0.841317 \\
Cross-section Chi-square & 0.840961 \\
\hline Cross-section F & 0.866771 \\
Cross-section Chi-square & 0.866593 \\
\hline Cross-section F & 0.889911 \\
Cross-section Chi-square & 0.889911 \\
\hline Cross-section F & 0.887953 \\
Cross-section Chi-square & 0.887953 \\
\hline Cross-section F & 0.88555 \\
Cross-section Chi-square & 0.885461 \\
\hline Cross-section F & 0.885461 \\
Cross-section Chi-square & 0.885461 \\
\hline
\end{tabular}

Source: Results of data with Eviews 6

Table 3 shows the results of regression analysis of panel data with fixed effect model. Based on the indicators R2 and the probability of $F$ statistics, it can be said that the models are built fit.

\section{Table 3. Regression Analysis with Fixed Effect Model}

\begin{tabular}{llllccl}
\hline $\begin{array}{c}\text { Dependent } \\
\text { variables }\end{array}$ & Constants & DAU & DAK & PAD & $\mathbf{R}^{2}$ & $\begin{array}{c}\text { Prob } \\
\text { (F-statistics) }\end{array}$ \\
\hline Y & $6.487^{* * *}$ & $0.411^{* * *}$ & $5,235^{* * *}$ & $1,884^{* * *}$ & 0.994 & 0.00 \\
Y1 & 1.840 & 0.178 & $4,551^{* * *}$ & $1,100^{* * *}$ & 0.997 & 0.00 \\
Y2 & 1,219 & 0.026 & $0.668^{* * *}$ & $0.330^{* * *}$ & 0.994 & 0.00 \\
Y3 & $2.402^{* * *}$ & $0,010^{* * *}$ & $-0.111^{* *}$ & $0,032^{* * *}$ & 0.992 & 0.00 \\
Y4 & $4,726^{* * *}$ & $0.018^{* *}$ & $-0.174^{* *}$ & $0.057^{* *}$ & 0.991 & 0.00 \\
Y5 & $2,292^{* * *}$ & $0.129^{* * *}$ & $-0.371^{*}$ & $0.129^{*}$ & 0.989 & 0.00 \\
Y6 & $1,058^{* * *}$ & $0.048^{* * *}$ & $-0.017^{* *}$ & $0.233^{* * *}$ & 0.989 & 0.00 \\
Y7 & $-6.192^{* *}$ & 0.003 & $0.663^{* *}$ & -0.003 & 0.995 & 0.00 \\
\hline
\end{tabular}


Local Revenue (PAD), General Allocation Fund (DAU), Special Allocation Fund (DAK), have a significant and positive effect on the level of 1 percent $(\alpha=1 \%)$ to total regional expenditure. Although equally significant at 1 percent level, however, the PAD coefficient is greater than the DAU coefficient. This means that it does not happen flypaper on local expenditure in Yogyakarta.

Local Revenue (PAD) and the Special Allocation Fund (DAK) effect a significant and positive at the level of 1 percent $(\alpha=1 \%)$ of the personnel expenditure, while the General Allocation Fund (DAU) is not significant. This indicates that the sub expenditure areas - personnel expenditure do not occur flypaper. On spending on goods and services that have a significant effect only Local Revenue (PAD). With can thus be said that the spending on goods and services does not happen flypaper area because governments tend to meet expenditures for goods and services with PAD.

General Allocation Grant (DAU) and Local Revenue (PAD) have a significant effect on official travel expenses. If seen from coefficient DAU and $\mathrm{PAD}$, in the category of official travel expenditures do not occur fypaper. In maintenance expenditure, the only sinifikan variable which is local revenue (PAD). Thus it can be said does not happen flypaper on maintenance expenditures. In this analysis, there is no relation between Local Own Revenue (PAD) and capital expenditure. This means that capital expenditure met from the General Allocation Grant (DAU), so that in the case of capital expenditure sub flypaper.

General Allocation Grant (DAU) and Local Revenue (PAD) effect significant and positive on 1 percent level $(\alpha=1 \%)$ against Expenditure For Results and Financial help. If the terms of the magnitude of the regression coefficients, then Expenditure For Results and Regions financial help no happen flypaper. In this analysis, it is found that the Special Allocation 
Fund (DAK) is the only variable that has significant effect on unexpected expenditure. Local Revenue (PAD) and General Allocation Grant show an insignificant relationship.

\section{Conclusion}

Transfer inter-government is one form of policy autonomy in addressing the fiscal gap. Transfer Award was faced with a common phenomenon in the success of regional development is the increase in regional spending in line with the increasing transfer of funds from the government. The main purpose of the transfer exercise is to internalize the fiscal externalities that arise in inter-regional development. Giving transfer basically aims to increase local capacity to finance local expenditure greater than transfer administration to increase local governments' efforts excavation area financing sources primarily from the fiscal area. However, the provision of transfer resulting in inefficiencies in the financing of regional spending, known as flypaper.

This study focused on identifying the flypaper effect on expenditure areas and classification with samples of 5 districts and cities in the province, in 2006-2015. The analysis showed that during the period between fypaper does not occur in the expenditure area and sub expenditure areas. Flypaper found only in capital expenditure and expenditure is not a suspect. This study only identify the occurrence of flypaper on local government districts and cities in the province with the benchmark significance of PAD and DAU to expenditure areas. Hence the advice that can be delivered is that further research can focus more on identifying flypaper in each city and county governments with more complex indicators. 


\section{References}

Auerbach, Alan J. and William G. Gale. (2009). The Economic Crisis and the Fiscal Crisis: 2009 and Beyond. California: Burch Center for Tax Policy and Public Finance at the University of California, Berkeley

Baskaran, T. (2016). Intergovernmental Transfers, Local Fiscal Policy, and the Flypaper Effect: Evidence from a German State. Finanz Archiv 72(1), 1-40.

Hermani, A. (2007). Impact Decentralization Fiscal to Economy in district Brebes and the City of Tegal. Thesis Magíster Science. Post Graduate program Bachelor Intitut Agriculture, Bogor.

Isdijoso, Brahmantio. (2002). Analysis Policy Fiskal Pada Era Otonomi Daerah (Studi Kasus : Sektor Education di Kota Surakarta). Study Economics and Keuangan Vol. 6 No. 1, 2002.

Jeyhoon-Tabar, F., Maddah, M. (2016). Studying the Flypaper Effect in The Provinces of Iran (2000-2013). Iranian Economic Review 20(3), 337-354.

Karnik, Ajit, and Mala Lalvani. (2008). "Flypaper Effect Incorporating Spatial Interdependence." Review of Urban \& Regional Development Studies 20, no. 2: 86-102.

Kim, Jungbu. (2007). Do Different Expenditure Mechanisms Invite Different Influences? Evidence From Research Expenditures Of The National Institutes OfHealth. Georgia State University and the Georgia Institute of Technology.

Leduc, S., Wilson, D. (2017). Are State Governments Roadblocks to Federal Stimulus? Evidence on the Flypaper Effect of Highway Grants in the 2009 Recovery Act. American Economic Journal: Economic Policy 9(2), 253-292.

Lewis, Blane D. (2003). Some Empirical Evidence on New Regional Taxes and Charges in Indonesia. Research Triangle Institute, North Carolina, USA. 
Maimunah , Mutiara . (2006). Flypaper Effect Pada Dana Alokasi Umum (DAU) dan Income Asli Daerah (PAD) terhadap Belanja Daerah Pada Kabupaten / Kota di Pulau Sumatra. SNA IX, Padang 23-26 Agustus 2006

Marothia, D.. (2010). Decentralisation of Natural Resource Management in India: An Institutional Perspective*. Indian Journal of Agricultural Economics 65, no. 1, (January 1): 1-34.

Mauro, Paolo. (2005). Corruption and the composition of government expenditure. International Monetary Fund. Journal of Public Economics 69 (1998) 263-279

Melo, Ligia. (2005). The Flypaper Effect under Different Institutional Contexts: The Colombian Case. Public Choice 111, no. 3-4, (April 1): 317345 .

Permendagri Nomor 13 Tahun 2006

Persha, L., and T. Blomley. (2009). Management Decentralization and Montane Forest Conditions in Tanzania. Conservation Biology 23, no 6 (Dec 1): 1485-1496.

PP Nomor 58 Tahun 2005

Prakosa, Kesit Bambang. (2004). Analysis Pengaruh Dana Alokasi Umum (DAU) dan Income Asli Daerah (PAD) Terhadap Prediksi Belanja Daerah (studi empiric di wilayah Propinsi Jawa Tengah dan DIY). JAAI. Vol. 8 No. 2, 2004.

Purbadharmaja, Ida Bagus Putu. (2007). Study To Function Budget Dalam Pembangunan Ekonomi Daerah. Buletin Studies Ekonomi Volume 12 Nomor 3 Tahun 2007

Regulska, J. (2009). Governance or Self-governance in Poland? Benefits and Threats 20 Years Later. International Journal of Politics, Culture, and Society 22, no. 4, (December 1): 537-556.

Richard Peck. (2005). Local Governance In Africa: The Challenges Of Democratic Decentralization. Review of Africa Today 51, no. 3, (April 
1): $138-140$.

Robinson, Peter dan Harun. (2004). Reforming The Indonesian Public Sector: The Introduction of Accrual Accounting. Accepted for Presentation at the Fourth Asia Pacific Interdisciplinary Research in Accounting Conference 4 to 6 July 2004 Singapore

Roy, S., Ara, J., Das, N., Quisumbing, A.R. (2015). "Flypaper Effects” in Transfers Targeted to Women: Evidence from BRAC's "Targeting the Ultra Poor” Program in Bangladesh. Journal of Development Economics $117,1-19$.

Seabright, Paul. (2005). Accountability and decentralisation in government: An incomplete contracts model. European Economic Review . Vol. 40 (1996) 61-89

Siregar, B., Badrudin, R. (2017). Degree of Fiscal Decentralization and Flypaper Effect: Evidence from Indonesia. Advanced Science Letters 23(9), 9013-9019.

Stephen J Bailey, \& Stephen Connolly. (2008). The flypaper effect: Identifying areas for further research. Public Choice (1986-1998), 95(3-4), 335. Retrieved May 18, 2013, from ProQuest Sociology. (Document ID: 618057781).

Sundatoko, Djoko. (2003). Dilema Otonomi Daerah. Yogyakarta: Andi .

Teferi, Abate. (2004). 'Decentralised there, centralised here': local governance and paradoxes of household autonomy and control in north-east ethiopia, 1991-2001. Africa 74, no. 4, (January 1), 611632.

UU No. 33 tahun 2004

UU Pajak Daerah dan Retribusi Daerah Tahun 2009

Venter, Denis. (2007). Democracy And Multiparty Politics In Africa. Eassrr, vol. XIX, no. 1 (January 2007)

Warner, M. (2009). Civic government or market-based governance? The limits of privatization for rural local governments. Agriculture and 
374 Muh. Rudi Nugroho

Human Values 26, no. 1-2, (March 1), 133-143.

William, Gavin. (2008). Target zone dynamics where the fundamental follows a SDE with periodic forcing. Monetary Authorities - Central Bank, Sep/Oct2005, Vol. 87 Issue 5, 633-658.

Winarno, Wing Wahyu. (2009). Analysis Ekonometrika and Statistics with Eviews. Yogyakarta: UPP STIM YKPN

Yuliadi, Imamudin. (2007). Perekonomian Indonesia: Masalah and Implementasi. Yogyakarta: UPFE UMY. 


\section{Shirkah Author Guidelines}

Shirkah currently offers two routes to submit manuscripts. We highly recommend to submit the articles which are made using OJS (Open Journal System). Feel free register as author soon through visiting http:// shirkah.or.id/index.php/home/user/register. The authors may directly send their manuscripts, along with their resume, to shirkahiainsurakarta@ gmail.com. Please prepare your manuscripts, using following guidelines:

1. Manuscript must be written in English. Submitted articles should not have been published or be under review for publication with another journal.

2. Manuscript's length is about $15-20$ pages, typed in one-half spaced on A4-paper size.

3. Manuscript must include an $150-200$ word abstract and keywords.

4. Manuscript must be arranged as follows: Title, Name of Author, E-mail address, Abstract, Keywords, Introduction (including method if any), Discussion, Conclusion, References.

5. Manuscript's titles not more than ten words.

6. Manuscript must be submitted in Microsoft Word or RTF.

7. Arabic words should be transliterated according to the style of International Journal of Middle Eastern Studies.

8. Manuscript references are preferably derived from the up-to-date references.

9. The author's resume should be submitted separately, consisting of at least full name, institutional address, phone number, areas of studies, and recent publications (if any).

10. Shirkab use APA Style 6th edition (2010) as reference format writing. We suggest the use of a reference manager software such as Mendeley, Zotero, and Endnote at templating the citation style. APA Style to be used is as follows: 


\section{Book with single author}

Swann, G. M. Peter. (2014). The Economics of Innovation an Introduction. Cheltenhum \& Northampton: Edward Elgar.

in-text citation: (Swann, 2014)

\section{Articles in reference books}

Alatas, S. F. (2006). Islam and the Science of Economics in Abu Rabi', I.M. The Blackwell Companion to Contemporary Islamic Thought. USA: Willey-Blackwell (pp. 587-606).

in text citation: (Alatas, 2006)

\section{E-Book}

Hackett, Rosalind (2007). "Religous Dimentions of War and Peace: Introduction." Dalam Gerrie ter Haar dan Yoshio Tsuruoka (Ed.), Religion and Society: An Agenda for the 21st Century (h. 3-6). Retrieved from http:// brill.nl.

in text citation: (Hackett, 2006)

\section{Master's thesis, from a commercial database}

McNieI, D. S. (2006). Meaning through narrative: A personal narrative discussing growing up with an alcoholic mother (Master's thesis). Available from ProQuest Dissertations and Theses database. (UMI No. 1434728)

in text citation: (Mc Niel, 2006)

\section{Doctoral dissertation, from an institutional database}

Adams, R. J. (1973). Building a foundation for evaluation of instruction in higher education and continuing education (Doctoral dissertation). Retrieved from http://www.ohiolink.edu/etd/

in text citation: (Adams, 1973) 


\section{Doctoral dissertation, from the web}

Bruckman, A. (1997). MOOSE Crossing: Construction, community, and learning in a networked virtual world for kids (Doctoral dissertation, Massachusetts Institute of Technology). Retrieved from http:/www-static. cc.gatech.edu/--asb/thesis/

in text citation: (Bruckman, 1997)

\section{Journal article with No DOI}

Bourkhis, K., and Nabi, M. S. (2013). Islamic and conventional banks' soundness during the 2007-2008 financial crisis. Journal Metrics, 22(2), 68-77.

in-text citation: (Bourkhis \& Nabi, 2013).

\section{Journal article with DOI}

Ichwan, M. (2012). The Local Politics Of Orthodoxy: The Majelis Ulama Indonesia in the Post-New Order Banten. Journal Of Indonesian Islam, 6(1), 166-194. doi:http://dx.doi.org/10.15642/JIIS.2012.6.1.166-194

In text citation : (Ichwan, 2012)

\section{Abstract as citation}

Hasan, N. (2012). Islamist Party, Electoral Politics And Da'wah Mobilization Among Youth : The Prosperous Justice Party (PKS) in Indonesia. Journal of Indonesian Islam, 6(1), 17-47. Abstract from http:// jiis.uinsby.ac.id/index.php/jiis/article/view/97

in text citation : (Hasan, 2012)

\section{Mass media article}

Sahal, Akhmad (2014, March 2). Kiai Sahal dan Realisme Fikih.Tempo Magazine, p. 120.

in text citation : (Sahal, 2014) 


\section{Research report}

Fisher, B. S., Cullen, F. T., \& Turner, M. G. (2000). The Sexual Victimization of College Women. Research Report.

in text citation : (Fisher, Cullen, Turner, 2000)

\section{Monograph}

Routray, Bibhu Prasad (2013), National Security Decision-Making in India (RSIS Monograph No. 27). Singapura: Rajaratnam School of International Studies.

in text citation : (Routray, 2013)

\section{Proceeding article}

Sudibyakto, Hizbaron, D.R., \& Jati, R (Ed.) (2009), Proceeding International Seminar Disaster Theory, Research and Policy. International seminar held by Sekolah Pascasarjana, Universitas Gajahmada, Yogyakarta, 8-9 Desember 2009.

in text citation : (sudibyakto and Jati, 2009)

\section{Paper conference/seminar/symposium}

Janutama, Herman Sinung (2011). "Kraton dan Hubungan Antar Agama." Paper presented in Seminar Kraton dan Panatagama held by Center for the Study of Islam and Social Transformation (CISForm), Yogyakarta, 17 November.

in text citation :(Janutama, 2011)

\section{Online article in web}

Shiva, (2006, February). Bioethics: A Third World Issue. Native-web. Diperoleh dari http://www.nativeweb.org/ pages/legal/shiva.html 
in text citation : (Shiva, 2006)

\section{Online research report}

Kessy, S. S. A., \& Urio, F M. (2006). The contribution of microfinance institutions to poverty reduction in Tanzania (Research Report No. 06.3). Retrieved from Research on Poverty Alleviation website: http://www. repoa.or.tz /documents_storage/Publications/Reports/06.3_Kessy_and_ Urio.pcif

in text citation : (kessy and urion, 2006)

\section{Holy book}

Qur an, $2(25)$

In text citation : (Q. al-Baqarah 2:25).

\section{Encyclopaedia}

Graycar, Adam (1992). Social Welfare Policy. Dalam Mary Hawkesworth dan Maurice Kogan (Ed.), Encyclopedia of Government and Politics (Vol. 1). London: Routledge.

in text citation : (Graycar, 1992)

\section{Interview}

Sultan Hamengkubuwono X (interview, 2011, April 19)

in text citation : (Hamengkubuwono, 2011)

\section{Documentary film}

Steijlen, Fridus (2008). A Day in the Life of Indonesia [documentary film, 58 minutes]. Leiden: KITLV Press.

in text citation : (Steijlen, 2008) 
Vol. 2 No. No. 3, September - December 2017 